Brazilian Journal

of Chemical

Engineering

\title{
ELEPHANT GRASS (Pennisetum purpureum Schumach) IS A PROMISING FEEDSTOCK FOR ETHANOL PRODUCTION BY THE THERMOTOLERANT YEAST Kluyveromyces marxianus CCT 7735
}

\author{
Breno B. Campos ${ }^{1}$, Raphael H. S. Diniz ${ }^{1,2}$, Fernando A. da Silveira', \\ José I. Ribeiro Júnior ${ }^{3}$, Luciano G. Fietto ${ }^{4}$, Juarez C. Machado ${ }^{5}$ and Wendel B. da Silveira ${ }^{*}$ \\ ${ }^{1}$ Universidade Federal de Viçosa, Departamento de Microbiologia, Instituto de Biotecnologia Aplicada à Agropecuária, Viçosa/MG, Brasil. \\ E-mail: wendel.silveira@ufv.br, ORCID: 0000-0001-7869-8144 \\ ${ }^{2}$ Instituto Federal de Educação, Ciência e Tecnologia de Minas Gerais, Ouro Preto/MG, Brasil. \\ ${ }^{3}$ Universidade Federal de Viçosa, Departamento de Estatística, Viçosa/MG, Brasil. \\ ${ }^{4}$ Universidade Federal de Viçosa, Departamento de Bioquímica e Biologia Molecular, Viçosa/MG, Brasil. \\ ${ }^{5}$ Embrapa Gado de Leite, Juiz de Fora/MG, Brasil.
}

(Submitted: May 18, 2017 ; Revised: January 7, 2018 ; Accepted: January 31, 2018)

\begin{abstract}
Elephant grass (Pennisetum purpureum Schumach) is regarded as a promising feedstock for second generation ethanol production, due to its high cellulose content, biomass production and rapid growth. The yeast Kluyveromyces marxianus CCT 7735 is capable of producing ethanol from agroindustrial residues, such as lignocellulosic biomass. Therefore, this study aimed to establish the optimal conditions for ethanol production by $K$. marxianus CCT 7735 from elephant grass. Five factors were evaluated: temperature (35$\left.45^{\circ} \mathrm{C}\right), \mathrm{pH}(4.5-5.8)$, agitation $(50-150 \mathrm{rpm})$, cellulase concentration $(7.5-22.5 \mathrm{FPU} / \mathrm{mL})$ and elephant grass biomass $(8-16 \% \mathrm{w} / \mathrm{v})$. Enzymatic concentration $(22.5 \mathrm{FPU} / \mathrm{mL})$, biomass concentration $(16 \% \mathrm{w} / \mathrm{v})$ and temperature $\left(38{ }^{\circ} \mathrm{C}\right)$ were the significant optimized factors. K. marxianus CCT 7735 produced a high ethanol concentration (around $45.5 \mathrm{~g} / \mathrm{L}$ ) under these optimized conditions, which is considered feasible in terms of energy requirements in the distillation step.

Keywords: Lignocellulosic biomass; Optimization; Renewable sources; Saccharification; Second-generation ethanol.
\end{abstract}

\section{INTRODUCTION}

The demand for renewable energy sources, mainly those produced from feedstocks that do not compete with food production, has increased over the last decades (Jonker et al., 2015). Indeed, there is great interest in ethanol production from lignocellulosic biomass, a non-food feedstock. In the worldwide over 2 Gha of land are degraded or non-arable soils with little application in agriculture; therefore, they may be suitable for energy crop cultivation (Lemus and Lal, 2005). Napier or elephant grass (Pennisetum purpureum Schumach) may be cultivated in deforested grazing lands that are not suited for food production without significant investment in soil preparation (Fontoura et al., 2015; Yasuda et al., 2014). In fact, this tropical plant, native to Africa, was introduced into South America and Australia as forage for livestock over a century ago for requiring little supplementary nutrients for growth, and able to be harvested up to four times a year (Basso et al., 2014).

\footnotetext{
*Corresponding author: Wendel B. da Silveira - E-mail: wendel.silveira@ufv.br
} 
It is noteworthy that elephant grass displays a high growth rate, $40 \mathrm{t} / \mathrm{ha}$ year of dry biomass per annum (Strezov et al., 2008). This rate is superior to those obtained for sugarcane and corn, which were approximately $21 \mathrm{t} / \mathrm{ha}_{\mathrm{x}}$ year (sugar and bagasse) and 13 t/ha year (grain and stover), respectively (Somerville et al., 2010). The features aforementioned highlight the elephant grass potential as a promising feedstock for second generation ethanol production, mainly in Brazil which has an estimated 100 Mha of land facing desertification (Fontoura et al., 2015). Ethanol production by Saccharomyces cerevisiae, a non-thermotolerant yeast commonly used in distilleries, is impaired at high growth temperatures. Therefore, in tropical countries like Brazil, it is necessary to cool the bioreactor, which raises the costs of ethanol production. (Abdel-Banat et al., 2010). Therefore, thermotolerant yeasts such as Kluyveromyces marxianus may enable the decrease of cooling costs. In addition, these yeasts are desirable for ethanol cellulosic production, because the optimum temperature for cellulolytic enzymes ranges commonly from 40 to $50{ }^{\circ} \mathrm{C}$ (Ballesteros et al., 2004).

Contrary to $S$. cerevisiae, $K$. marxianus CCT 7735 (previously designated as UFV-3) is able to ferment different sugars into ethanol at high temperatures. $K$. marxianus CCT 7735 produced second-generation ethanol from cheese whey permeated with ethanol yields above 90\% in temperature between 33.5-38.5 ${ }^{\circ} \mathrm{C}$ and lactose concentration between 50-108 g/L (Diniz et al., 2014; Silveira et al., 2005). Interestingly, $K$. marxianus CCT 7735 also produces ethanol efficiently from either sugarcane bagasse or a mixture of sugarcane bagasse and ricotta whey (Ferreira et al., 2015; Souza et al., 2012).

Although elephant grass presents potential to be used as raw material for ethanol production, there are few studies focusing on its production by $K$. marxianus from this feedstock. Thus, the purpose of this study was to define the optimal conditions (temperature, $\mathrm{pH}$, agitation, biomass, and enzyme concentration) for the ethanol production by $K$. marxianus CCT 7735 from elephant grass biomass.

\section{MATERIAL AND METHODS}

\section{Yeast strain and maintenance}

Kluyveromyces marxianus CCT 7735 was stored and maintained in the culture collection at the Laboratory of Microorganism Physiology. The inoculum for fermentation was prepared by adding $1 \%(\mathrm{w} / \mathrm{v})$ of the biomass stored at $-80{ }^{\circ} \mathrm{C}$ into YPD medium ( $2 \%$ peptone, $1 \%$ yeast extract, $2 \%$ glucose) and cultivated under agitation $(200 \mathrm{rpm})$, at $37^{\circ} \mathrm{C}$ for 18-24 h. Thus, cells were centrifuged (3,000 g, $5 \mathrm{~min})$, washed with sterile water, and inoculated into the fermentation medium.

\section{Raw material}

Elephant grass (Pennisetum purpureum Schumach) cultivar BRS Capiaçu, was developed by the Elephant Grass Breeding Program of the Brazilian Agricultural Research Corporation (Embrapa) and cultivated in Coronel Pacheco, Minas Gerais, Brazil (213'18"S, $43^{\circ} 15^{\prime} 51^{\prime \prime} \mathrm{W}$, at $417 \mathrm{~m}$ altitude). The biomass was dried, crushed and passed through a metal sieve of $70 \mathrm{MESH}$ separating particles of $0.21 \mathrm{~mm}$.

\section{Biomass pretreatment}

Elephant grass, crushed 10\% (w/v), was pretreated in $0.5 \%(\mathrm{v} / \mathrm{v}) \mathrm{H}_{2} \mathrm{SO}_{4}$, at $121{ }^{\circ} \mathrm{C}$ for $30 \mathrm{~min}$. The solid and liquid fractions were separated by vacuum filtration through filter paper (Whatman $\mathrm{N}^{\mathrm{o}}$. 5; GE Healthcare, LC, UK). The solid residue was washed with distilled water and dried at $53{ }^{\circ} \mathrm{C}$ for $24 \mathrm{~h}$. Dried biomass $(5.7 \% \mathrm{w} / \mathrm{v})$ was subjected to second-step pretreatment with $1.5 \%$ sodium hydroxide solution (w/v) at $100{ }^{\circ} \mathrm{C}$ for $2 \mathrm{~h}$. Pretreated biomass was washed and dried under the same conditions described above. Cellulose, lignin, and water concentrations of elephant grass biomass were determined using standardized methods (Komarek, 1993; Silva and Queiroz, 1981).

\section{Fermentation medium}

The fermentation medium was: yeast extract $(2.5 \mathrm{~g} / \mathrm{L})$, peptone $(2.5 \mathrm{~g} / \mathrm{L}), \mathrm{NH}_{4} \mathrm{Cl}(2.0 \mathrm{~g} / \mathrm{L}), \mathrm{KH}_{2} \mathrm{PO}_{4}$ $(1.0 \mathrm{~g} / \mathrm{L}), \quad \mathrm{MgSO}_{4} .7 \mathrm{H}_{2} \mathrm{O}(0.3 \mathrm{~g} / \mathrm{L})$ and different concentrations of elephant grass biomass obtained in the pretreatment process.

\section{Fermentation assays}

Fermentation experiments were carried out in $125 \mathrm{~mL}$ flasks containing $50 \mathrm{~mL}$ of fermentation medium, buffered with citrate buffer $(5 \mathrm{mmol} / \mathrm{L})$. A pre-saccharification step was performed by adding $60 \mathrm{FPU} / \mathrm{mL}$ of cellulase (Celluclast $1.5 \mathrm{~L}$, Sigma ${ }^{\circledR}$, St. Louis, MO, USA), at $50{ }^{\circ} \mathrm{C}$ for $72 \mathrm{~h}$, in gentle agitation. Then, the inoculum $\left(\mathrm{A}_{600 \mathrm{~mm}}=2.0\right)$ was added and nitrogen gas $(99.9 \%)$ was purged for $15-\mathrm{min}$ to reach hypoxia. The fermentation processes were conducted at the temperature, $\mathrm{pH}$, agitation, cellulase and biomass concentrations described in Table 1. Samples were taken periodically to evaluate the sugar consumption and ethanol production.

\section{Sugar and primary metabolite analysis}

To determine the concentrations of glucose, xylose, cellobiose, glycerol, and ethanol, samples were taken from the fermentation experiments and applied to a high-performance liquid chromatography (HPLC) system (LC-20AT, SHIMADZU Co. Ltd., Kyoto, Japan) using a Rezex ROAO organic acid $\mathrm{H}^{+}$column, with $5.0 \mathrm{mmol} / \mathrm{L} \mathrm{H}_{2} \mathrm{SO}_{4}$ eluent at a flow of $0.6 \mathrm{~mL} / \mathrm{min}$ and column temperature at $45^{\circ} \mathrm{C}$. 
Table 1. Experimental matrix analysing ethanol production according to factorial design.

\begin{tabular}{|c|c|c|c|c|c|c|c|c|}
\hline \multirow[t]{2}{*}{ Assay } & \multirow{2}{*}{$\begin{array}{c}\text { Temperature } \\
\left({ }^{\circ} \mathrm{C}\right)\end{array}$} & \multirow[t]{2}{*}{ pH } & \multirow{2}{*}{$\begin{array}{c}\text { Agitation } \\
\text { (rpm) }\end{array}$} & \multirow{2}{*}{$\begin{array}{c}\text { Enzyme } \\
\text { (FPU/mL) }\end{array}$} & \multirow{2}{*}{$\begin{array}{c}\text { Biomass } \\
(\%)\end{array}$} & $\begin{array}{c}\text { Glucose } \\
\text { concentration* }\end{array}$ & $\begin{array}{c}\text { Xylose } \\
\text { concentration* }\end{array}$ & $\begin{array}{c}\text { Ethanol } \\
\text { production }\end{array}$ \\
\hline & & & & & & \multicolumn{3}{|c|}{$(\mathrm{g} / \mathrm{L})$} \\
\hline 1 & 35 & 4.5 & 50 & 7.5 & 8 & 29.7 & 6.0 & 19.3 \\
\hline 2 & 35 & 5.8 & 50 & 7.5 & 8 & 24.0 & 4.4 & 18.4 \\
\hline 3 & 45 & 4.5 & 50 & 7.5 & 8 & 31.8 & 6.7 & 17.3 \\
\hline 4 & 45 & 5.8 & 50 & 7.5 & 8 & 21.5 & 3.9 & 15.6 \\
\hline 5 & 35 & 4.5 & 150 & 7.5 & 8 & 33.5 & 6.7 & 19.0 \\
\hline 6 & 35 & 5.8 & 150 & 7.5 & 8 & 24.0 & 4.2 & 17.9 \\
\hline 7 & 45 & 4.5 & 150 & 7.5 & 8 & 31.4 & 6.2 & 18.5 \\
\hline 8 & 45 & 5.8 & 150 & 7.5 & 8 & 22.5 & 4.0 & 17.3 \\
\hline 9 & 35 & 4.5 & 50 & 22.5 & 8 & 40.4 & 8.4 & 23.0 \\
\hline 10 & 35 & 5.8 & 50 & 22.5 & 8 & 30.4 & 5.5 & 23.0 \\
\hline 11 & 45 & 4.5 & 50 & 22.5 & 8 & 39.3 & 8.1 & 21.9 \\
\hline 12 & 45 & 5.8 & 50 & 22.5 & 8 & 28.7 & 5.4 & 19.9 \\
\hline 13 & 35 & 4.5 & 150 & 22.5 & 8 & 44.1 & 8.5 & 22.1 \\
\hline 14 & 35 & 5.8 & 150 & 22.5 & 8 & 31.2 & 5.4 & 23.2 \\
\hline 15 & 45 & 4.5 & 150 & 22.5 & 8 & 42.8 & 8.3 & 21.8 \\
\hline 16 & 45 & 5.8 & 150 & 22.5 & 8 & 30.4 & 5.2 & 22.4 \\
\hline 17 & 35 & 4.5 & 50 & 7.5 & 16 & 49.6 & 10.2 & 37.2 \\
\hline 18 & 35 & 5.8 & 50 & 7.5 & 16 & 33.6 & 5.7 & 30.8 \\
\hline 19 & 45 & 4.5 & 50 & 7.5 & 16 & 50.7 & 10.3 & 27.2 \\
\hline 20 & 45 & 5.8 & 50 & 7.5 & 16 & 31.4 & 5.7 & 19.2 \\
\hline 21 & 35 & 4.5 & 150 & 7.5 & 16 & 47.5 & 9.6 & 34.4 \\
\hline 22 & 35 & 5.8 & 150 & 7.5 & 16 & 35.8 & 6.2 & 33.2 \\
\hline 23 & 45 & 4.5 & 150 & 7.5 & 16 & 47.9 & 9.1 & 23.4 \\
\hline 24 & 45 & 5.8 & 150 & 7.5 & 16 & 34.8 & 6.2 & 25.9 \\
\hline 25 & 35 & 4.5 & 50 & 22.5 & 16 & 65.6 & 13.3 & 44.0 \\
\hline 26 & 35 & 5.8 & 50 & 22.5 & 16 & 50.1 & 8.8 & 44.8 \\
\hline 27 & 45 & 4.5 & 50 & 22.5 & 16 & 61.9 & 12.7 & 32.0 \\
\hline 28 & 45 & 5.8 & 50 & 22.5 & 16 & 47.8 & 8.0 & 28.6 \\
\hline 29 & 35 & 4.5 & 150 & 22.5 & 16 & 64.9 & 13.2 & 43.0 \\
\hline 30 & 35 & 5.8 & 150 & 22.5 & 16 & 50.3 & 9.0 & 43.7 \\
\hline 31 & 45 & 4.5 & 150 & 22.5 & 16 & 62.2 & 12.5 & 26.2 \\
\hline 32 & 45 & 5.8 & 150 & 22.5 & 16 & 48.1 & 8.3 & 32.5 \\
\hline 33 & 40 & 5.2 & 100 & 15 & 12 & 42.2 & 8.2 & 33.6 \\
\hline
\end{tabular}

*Glucose and xylose release after enzymatic treatment.

\section{Experimental design}

Factorial design was applied to determinate the effect of 5 independent variables - temperature $\left(35-45{ }^{\circ} \mathrm{C}\right)$, agitation (50-150 rpm), $\mathrm{pH}$ (4.5-5.8), cellulase (7.5$22.5 \mathrm{FPU} / \mathrm{mL})$, and biomass concentration $(8-16 \% \mathrm{w} / \mathrm{v})$ - on the ethanol production (dependent variable). The experiments were performed in a completely randomized design composed of 33 experimental units (Table 1). A statistical model that describes the relation between dependent and independent variables was obtained based on a first-order equation with double interactions.

$$
\begin{aligned}
\mathrm{y} & =\beta_{0}+\beta_{1}[\text { Temperature }]+\beta_{2}[\mathrm{pH}]+\beta_{3}[\text { Agitation }]+\beta_{4}[\text { Enzyme }]+ \\
& +\beta_{5}[\text { Biomass }]+\beta_{6}[\text { Temperature } \times \mathrm{pH}]+\beta_{7}[\text { Temperature } \times \text { Agitation }]+ \\
& +\beta_{8}[\text { Temperature } \times \text { Enzyme }]+\beta_{9}[\text { Temperature } \times \text { Biomass }]+ \\
& +\beta_{10}[\mathrm{pH} \times \text { Agitation }]+\beta_{11}[\mathrm{pH} \times \text { Cellulase }]+\beta_{12}[\mathrm{pH} \times \text { Biomass }]+ \\
& +\beta_{13}[\text { Agitation } \times \text { Cellulase }]+\beta_{14}[\text { Agitation } \times \text { Biomass }]+ \\
& +\beta_{15}[\text { Cellulase } \times \text { Biomass }]+\varepsilon_{\mathrm{i}}
\end{aligned}
$$

where: $y$ is the observed value of the response variable; $\beta_{0}$ is the intercept coefficient, $\beta_{1}$ to $\beta_{15}$ are the regression coefficients, and $\varepsilon$ is the normally, independent and identically distributed error. The model and the significance of each coefficient were determined using the Student's $t$ test $(p<0.05)$ and the equation fit was expressed by determination coefficient $\mathrm{R}^{2}$. All analyses were performed employing Minitab ${ }^{\circledR} 17$ software (Minitab Inc., State College, PA, USA). The model was validated through bias and accuracy factors based on repetitions at the ideal conditions proposed by statistical model.

- Bias factor $\left(F_{B}\right)$ :

$$
\mathrm{F}_{\mathrm{B}}=10^{\left[\sum \frac{\log \left(\frac{\mathrm{p}}{\mathrm{o}}\right)}{\mathrm{n}}\right]}
$$

$$
\text { - Accuracy factor }\left(\mathrm{F}_{\mathrm{A}}\right) \text { : }
$$

$$
\mathrm{F}_{\mathrm{A}}=10^{\left[\frac{\log \left(\frac{\mathrm{P}}{\mathrm{O}}\right)}{\mathrm{n}}\right]}
$$

where $\mathrm{P}$ is the predicted value of the response variable, $\mathrm{O}$ is the observed value of the response variable, and $\mathrm{n}$ is the number of repetitions of the validation. 


\section{RESULTS AND DISCUSSION}

Dilute acid and alkaline pretreatments have been recognized as an efficient procedure of cellulose recovery from lignocellulosic biomass (Camesasca et al., 2015; Yasuda et al., 2014). In order to retrieve high cellulose concentrations, the elephant grass biomass was subjected to both dilute acid and alkaline pretreatments. The pretreatments were efficient, since both the cellulose and lignin concentrations increased from 38 to $76.30 \%$ and from 7.60 to $8.20 \%$, respectively, resulting in lignin/cellulose ratio diminished from 0.20 to 0.11 (data not shown). These results highlight the potential of the elephant grass as feedstock for ethanol production, because its high cellulose content can lead to a higher glucose release via enzymatic hydrolysis. Furthermore, the reduction of the lignin concentration is desirable, since the phenolic compounds, which are constituents of this polymer, can inhibit cellulases, hemicellulases and $\beta$-glucosidases (Kim et al., 2011). The $K$. marxianus CCT 7735 ability to produce ethanol from elephant grass was evaluated according to the factorial design described in the Material and Methods section (Table 1). In order to increase ethanol yield the fermentative process was preceded by a pre-saccharification step, similar to that performed in previous work (Souza et al., 2012).

We observed the glucose consumption and ethanol production in the earlier stages of the fermentative process, i.e., in the first $12 \mathrm{~h}$ of fermentation, which is desirable in industrial processes (data not show). The theoretical ethanol yield is 0.51 gram per gram of glucose consumed. This means, for example, that in assay 1 the maximum ethanol production would be $15.2 \mathrm{~g} / \mathrm{L}$, since $29.7 \mathrm{~g} / \mathrm{L}$ of glucose was obtained in the pre-saccharification step (Table 1). However, the maximum ethanol production was $19.3 \mathrm{~g} / \mathrm{L}$, indicating that the cellulases continue hydrolysing cellulose to glucose during fermentation (Table 1). This cellulase activity demonstrates that saccharification occurred simultaneously with fermentation, contributing to improve the ethanol production.

The highest ethanol productions, around $44 \mathrm{~g} / \mathrm{L}$, were obtained in the assays 25,26 and 30 in which the temperature, enzymatic and biomass concentrations were $35^{\circ} \mathrm{C}, 22.5 \mathrm{FPU} / \mathrm{ml}$ and $16 \%$, respectively (Table 1). In a lignocellulose-based process, the aim has been to reach at least $40-50 \mathrm{~g} / \mathrm{L}$ of ethanol, because the cost with the distillation is feasible in this concentration range (Todaro and Vogel, 2014). In this work, the ethanol titers obtained by $K$. marxianus CCT 7735 were superior to those obtained by some $S$. cerevisiae strains from elephant grass. S. cerevisiae Ethanol Red produced $26.1 \mathrm{~g} / \mathrm{L}$ of ethanol (Cardona et al., 2014), S. cerevisiae CAT-1 produced values inferior to $40.0 \mathrm{~g} / \mathrm{L}$ of ethanol (Scholl et al., 2015), and
S. cerevisiae (brewer's yeast) produced $23.4 \mathrm{~g} / \mathrm{L}$ of ethanol (Aiyejagbara et al., 2016) from elephant grass. In addition, it should be pointed out that the ethanol concentrations obtained in this work employing $K$. marxianus were higher than those achieved in studies that used other lignocellulosic biomasses as feedstock (Ballesteros et al., 2004; García-Aparicio et al., 2011; Kang et al., 2012; Tomás-Pejó et al., 2009), highlighting the potential of elephant grass as feedstock for cellulosic ethanol production.

Based on the ethanol production data obtained in our work, we performed the optimization of the fermentative process by analysing five factors: temperature, $\mathrm{pH}$, agitation, biomass and enzyme concentrations, as well as the interaction among them. The model was fitted ( $p$-value $<0.001$, $\mathrm{R}^{2}=0.93$ ) for the ethanol production from elephant grass biomass, in which the temperature, enzyme and biomass concentrations showed significant linear and interaction coefficients:

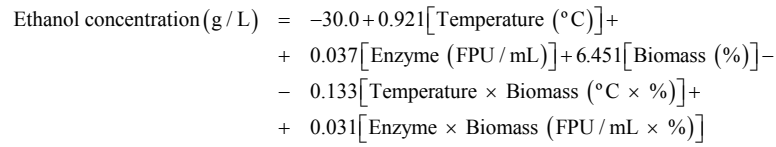

The results of the ANOVA, F, and $t$-test used in fitting the model, Equation 4, are summarized in Table 2 indicating that the model fit is appropriate to describe the ethanol production from elephant grass biomass by K. marxianus CCT 7735. The significant adjust of this factorial model showed that the optimal conditions for ethanol production were determined; therefore, it was not necessary to use other models such as the central composite rotational design (CCRD). Thus, the effects and relations of significant factors on ethanol production by $K$. marxianus CCT 7735 from elephant grass can be observed in Figures 1-3.

The combination of high biomass and enzyme concentrations yielded the highest ethanol production (Figure 1). These results are consistent with the higher glucose release in the aforementioned conditions,

Table 2. Analysis of variance - ANOVA - of the adjusted model for the ethanol production from elephant grass biomass by K. marxianus CCT 7735 .

\begin{tabular}{lcrrr}
\hline \multicolumn{1}{c}{ Source } & $\begin{array}{c}\text { Degree of } \\
\text { Freedom }\end{array}$ & $\begin{array}{r}\text { Sum of } \\
\text { squares }\end{array}$ & F & p-value \\
\hline Model & 5 & 2229.00 & 74.06 & 0.000 \\
Linear & 3 & 1976.56 & 109.46 & 0.000 \\
Temperature & 1 & 359.79 & 59.77 & 0.000 \\
Enzyme & 1 & 297.07 & 49.35 & 0.000 \\
Biomass & 1 & 1319.70 & 219.25 & 0.000 \\
Interaction & 2 & 252.45 & 20.97 & 0.000 \\
Temperature*Biomass & 1 & 225.25 & 37.42 & 0.000 \\
Enzyme*Biomass & 1 & 27.20 & 4.52 & 0.043 \\
Error & 27 & 162.52 & & \\
Total & 32 & 2391.52 & & \\
\hline
\end{tabular}




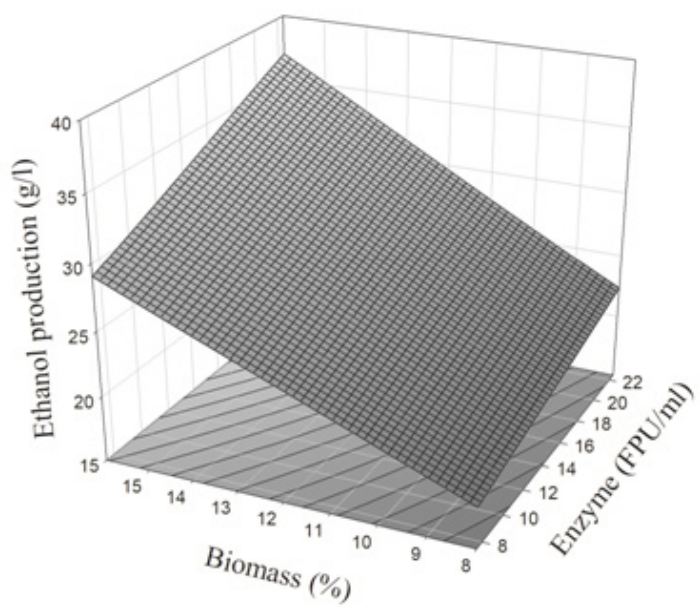

Figure 1. Response surface of ethanol production $(\mathrm{g} / \mathrm{L})$ as a function of enzyme concentration $(\mathrm{FPU} / \mathrm{mL})$ and biomass (\%) levels from elephant grass.

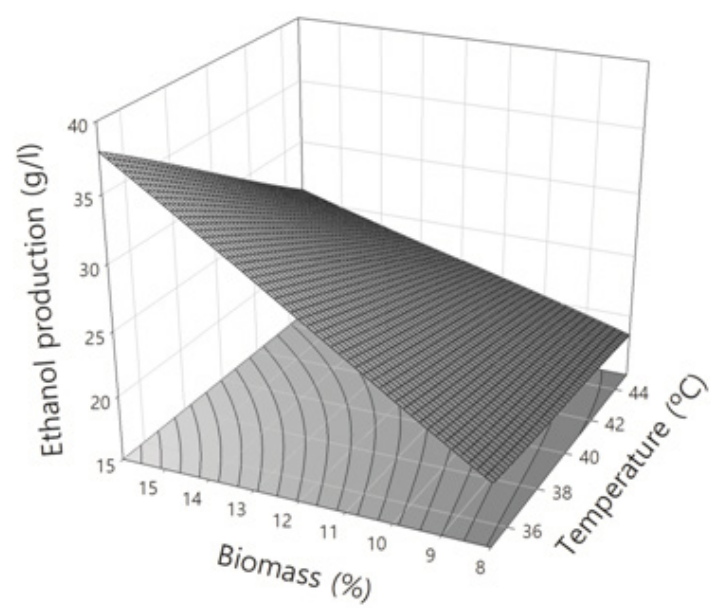

Figure 2. Response surface of ethanol production $(\mathrm{g} / \mathrm{L})$ as a function of temperature $\left({ }^{\circ} \mathrm{C}\right)$ and biomass (\%) levels from elephant grass.

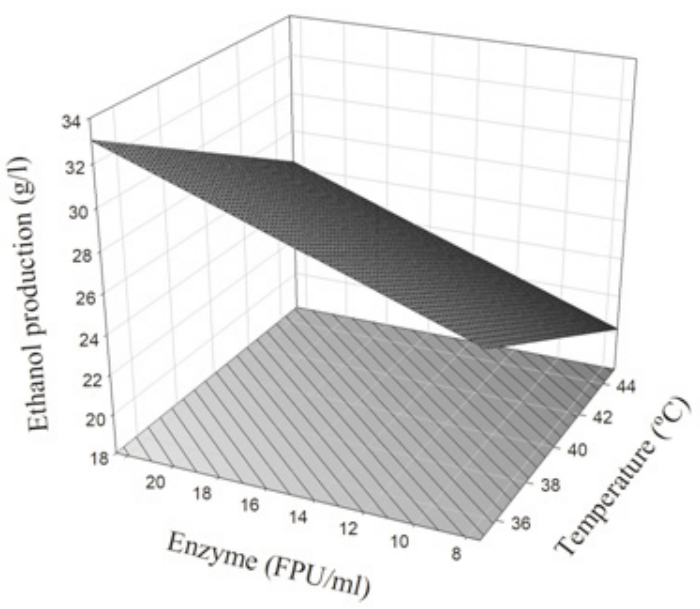

Figure 3. Response surface of ethanol production $(\mathrm{g} / \mathrm{L})$ as a function of temperature $\left({ }^{\circ} \mathrm{C}\right)$ and enzyme (FPU/mL) levels from elephant grass. which is crucial to improve the ethanol yields. However, biomass lignocellulosic cannot exceed certain values, because higher biomass loading leads to a higher viscosity and unfavourable mass transfer. In experiments conducted with different lignocellulosic biomass concentrations (up to $18 \%$ ), the maximum ethanol production obtained was $16 \%$, indicating that the high viscosity of the medium containing $18 \%$ biomass impaired the fermentative process (Kang et al., 2012). The use of increasing concentrations of elephant grass biomass (ranging from 4 to 20\%) also proved to be efficient to increase the ethanol production from $S$. cerevisiae CAT-1, with a maximum yield at the concentration of 16\% biomass (Menegol et al., 2016).

In our work, elephant grass biomass and temperature showed an inverse relation, i.e., the lower temperature $\left(35^{\circ} \mathrm{C}\right)$ and the higher biomass concentration (16\%) used in the experiments favoured ethanol production (Figure 2). In the interaction between temperature and enzyme concentration, the ethanol production was higher in the range 36 to 39 ${ }^{\circ} \mathrm{C}$ (Figure 3). Similar to the results observed in Figure 1 , the enzymatic concentration was proportional to ethanol concentration, i.e., the increase of the amount of cellulolytic enzymes led to the increase of the ethanol production.

Agitation was not significant; furthermore, it did not influence either the ethanol production or fermentation speed. The $\mathrm{pH}$ values chosen in this study were based on both the $\mathrm{pH}$ optimum of $K$. marxianus CCT 7735 fermentation (Diniz et al., 2014; Ferreira et al., 2015) and the $\mathrm{pH}$ used for saccharification of lignocellulosic biomass (Cardona et al., 2014; García-Aparicio et al., 2011; Menegol et al., 2016; Tomás-Pejó et al., 2009). Likely, the $\mathrm{pH}$ value was not significant because the $\mathrm{pH}$ range adopted was optimal for both cellulose hydrolysis and ethanol production by $K$. marxianus CCT 7735.

The optimized values of all significant factors were: temperature at $38{ }^{\circ} \mathrm{C}$, enzymatic and biomass concentrations of $22.5 \mathrm{FPU} / \mathrm{mL}$ and $16 \%$, respectively. Finally, the bias and accuracy factors were evaluated to test the reliability and suitability of the fitted model for predicting ethanol production (Equation 4). Batch fermentations were performed under the following conditions: temperature, $38^{\circ} \mathrm{C} ; \mathrm{pH}$ value, 4.8 ; biomass concentration, $16 \%$; enzyme concentration, $16 \mathrm{FPU} /$ $\mathrm{mL}$ and agitation, $50 \mathrm{rpm}$. In these conditions, $K$. marxianus CCT 7735 produced 45.1 and $45.5 \mathrm{~g} / \mathrm{L}$ of ethanol (data not shown). Taking into account Equation 1 , the ethanol values would be $39.4 \mathrm{~g} / \mathrm{L}$. Therefore, the values obtained for both bias factor (0.87) and accuracy factor (1.15) were within the expected concentrations, indicating that the model is reliable and suitable for estimating the ethanol production by $K$. marxianus CCT 7735 from elephant grass. 
Therefore, K. marxianus CCT 7735 was capable of fermenting at elevated temperatures under optimized conditions, with highest titer at $38{ }^{\circ} \mathrm{C}$ (around 45.5 $\mathrm{g} / \mathrm{L}$ ), which is desirable due to the reduction of the costs associated with cooling. This occurs because in the ethanol industry the fermentative process takes place traditionally at temperatures below $33{ }^{\circ} \mathrm{C}$ since high temperatures lead to a loss of cell viability of $S$. cerevisiae (Abdel-Banat et al., 2010). In fact, in tropical countries, where elephant grass grows faster than in temperate countries, the cooling costs of fermentation are more expensive (Abdel-Banat et al., 2010).

\section{CONCLUSION}

Elephant grass is a promising feedstock for the production of second generation ethanol production, because the ethanol concentrations obtained in this work were superior to those achieved from other lignocellulosic biomasses. K. marxianus CCT 7735 can be considered an alternative to $S$. cerevisiae for cellulosic ethanol production. Moreover, K. marxianus CCT 7735 produced ethanol in concentrations considered feasible in terms of energy requirements in the distillation step. Taken together, these results highlight the potential of $K$. marxianus CCT 7735 and elephant grass for second-generation ethanol production.

\section{ACKNOWLEDGEMENTS}

This work was supported by the Coordenação de Aperfeiçoamento de Nível Superior - Brasil (CAPES) - Finance code 001. This was also financed by the Brazilian Agencies Foundation for Research Support of the State of Minas Gerais (FAPEMIG) as well as National Science and Technology Development Council $(\mathrm{CNPq})$. We are also grateful to EMBRAPA for the support and helpful assistance with elephant grass breeding.

\section{REFERENCES}

Abdel-Banat, B.M., Hoshida, H., Ano, A., Nonklang, S. and Akada, R., High-temperature fermentation: how can processes for ethanol production at high temperatures become superior to the traditional process using mesophilic yeast?, Applied Microbiology and Biotechnology, 85, 861-867 (2010). https://doi.org/10.1007/s00253-009-22485

Aiyejagbara, M.O., Aderemi, B., Ameh, A., Ishidi, E., Ibeneme, E.F.A. and Olakunle, M., Production of Bioethanol from Elephant Grass (Pennisetum purpureum) Stem, International Journal of Innovative Mathematics, Statistics \& Energy Policies, 4, 1-9 (2016).
Ballesteros, M., Oliva, J.M., Negro, M.J., Manzanares, P. and Ballesteros, I., Ethanol from lignocellulosic materials by a simultaneous saccharification and fermentation process (SFS) with Kluyveromyces marxianus CECT 10875, Process Biochemistry, 39, 1843-1848 (2004). https://doi.org/10.1016/j. procbio.2003.09.011

Basso, V., Machado, J.C., da Silva Lédo, F.J., da Costa Carneiro, J., Fontana, R.C., Dillon, A.J. and Camassola, M., Different elephant grass (Pennisetum purpureum) accessions as substrates for enzyme production for the hydrolysis of lignocellulosic materials, Biomass and Bioenergy, 71, 155-161 (2014). https://doi.org/10.1016/j. biombioe.2014.10.011

Camesasca, L., Ramírez, M.B., Guigou, M., Ferrari, M.D. and Lareo, C., Evaluation of dilute acid and alkaline pretreatments, enzymatic hydrolysis and fermentation of napiergrass for fuel ethanol production, Biomass and Bioenergy, 74, 193-201 (2015). https://doi.org/10.1016/j. biombioe.2015.01.017

Cardona, E., Rios, J., Peña, J. and Rios, L., Effects of the pretreatment method on enzymatic hydrolysis and ethanol fermentability of the cellulosic fraction from elephant grass, Fuel, 118, 41-47 (2014). https://doi.org/10.1016/j.fuel.2013.10.055

Diniz, R.H.S., Rodrigues, M.Q.R.B., Fietto, L.G., Passos, F.M.L. and Silveira, W.B., Optimizing and validating the production of ethanol from cheese whey permeate by Kluyveromyces marxianus UFV3, Biocatalysis and Agricultural Biotechnology, 3, 111-117 (2014). https://doi.org/10.1016/j. bcab.2013.09.002

Ferreira, P.G., Silveira, F.A., Santos, R.C.V., Genier, H.L.A., Diniz, R.H.S., Ribeiro Jr, J.I., Fietto, L.G., Passos, F.M.L. and Silveira, W.B., Optimizing ethanol production by thermotolerant Kluyveromyces marxianus CCT 7735 in a mixture of sugarcane bagasse and ricotta whey, Food Science and Biotechnology, 24, 1421-1427 (2015). https://doi.org/10.1007/s10068-015-0182-0

Fontoura, C.F., Brandão, L.E. and Gomes, L.L., Elephant grass biorefineries: towards a cleaner Brazilian energy matrix?, Journal of Cleaner Production, 96, 85 (2015). https://doi.org/10.1016/j. jclepro.2014.02.062

García-Aparicio, M., Oliva, J., Manzanares, P., Ballesteros, M., Ballesteros, I., González, A. and Negro, M., Second-generation ethanol production from steam exploded barley straw by Kluyveromyces marxianus CECT 10875, Fuel, 90, 1624-1630 (2011). https://doi.org/10.1016/j. fuel.2010.10.052

Jonker, J., Van Der Hilst, F., Junginger, H., Cavalett, O., Chagas, M. and Faaij, A., Outlook for ethanol 
production costs in Brazil up to 2030, for different biomass crops and industrial technologies, Applied Energy, 147, 593-610 (2015). https://doi. org/10.1016/j.apenergy.2015.01.090

Kang, H.-W., Kim, Y., Kim, S.-W. and Choi, G.-W., Cellulosic ethanol production on temperature-shift simultaneous saccharification and fermentation using the thermostable yeast Kluyveromyces marxianus CHY1612, Bioprocess and Biosystems Engineering, 35, 115-122 (2012). https://doi. org/10.1007/s00449-011-0621-0

Kim, Y., Ximenes, E., Mosier, N.S. and Ladisch, M.R., Soluble inhibitors/deactivators of cellulase enzymes from lignocellulosic biomass, Enzyme and Microbial Technology, 48, 408-415 (2011). https://doi.org/10.1016/j.enzmictec.2011.01.007

Komarek, A., A filter bag procedure for improved efficiency of fiber analysis, Journal of Dairy Science, 76, 250 (1993).

Lemus, R. and Lal, R., Bioenergy crops and carbon sequestration, Critical Reviews in Plant Sciences, 24, 1-21 (2005). https://doi. org/10.1080/07352680590910393

Menegol, D., Fontana, R.C., Dillon, A.J.P. and Camassola, M., Second-generation ethanol production from elephant grass at high total solids, Bioresource Technology, 211, 280-290 (2016). https://doi.org/10.1016/j.biortech.2016.03.098

Scholl, A.L., Menegol, D., Pitarelo, A.P., Fontana, R.C., Filho, A.Z., Ramos, L.P., Dillon, A.J.P. and Camassola, M., Ethanol production from sugars obtained during enzymatic hydrolysis of elephant grass (Pennisetum purpureum, Schum.) pretreated by steam explosion, Bioresource Technology, 192, 228-237 (2015). https://doi.org/10.1016/j. biortech.2015.05.065

Silva, D. and Queiroz, A. Análise de alimentos: Métodos Químicos e Biológicos. UFV, Viçosa, (1981).
Silveira, W., Passos, F., Mantovani, H. and Passos, F., Ethanol production from cheese whey permeate by Kluyveromyces marxianus UFV-3: a flux analysis of oxido-reductive metabolism as a function of lactose concentration and oxygen levels, Enzyme and Microbial Technology, 36, 930-936 (2005). https://doi.org/10.1016/j.enzmictec.2005.01.018

Somerville, C., Youngs, H., Taylor, C., Davis, S.C. and Long, S.P., Feedstocks for lignocellulosic biofuels, Science, 329, 790-792 (2010). https://doi. org/10.1126/science. 1189268

Souza, C.J., Costa, D.A., Rodrigues, M.Q., Santos, A.F., Lopes, M.R., Abrantes, A.B., Santos Costa, P., Silveira, W.B., Passos, F.M. and Fietto, L.G., The influence of presaccharification, fermentation temperature and yeast strain on ethanol production from sugarcane bagasse, Bioresource Technology, 109, 63-69 (2012). https://doi.org/10.1016/j.biortech.2012.01.024

Strezov, V., Evans, T.J. and Hayman, C., Thermal conversion of elephant grass (Pennisetum Purpureum Schum) to bio-gas, bio-oil and charcoal, Bioresource Technology, 99, 8394-8399 (2008). https://doi.org/10.1016/j.biortech.2008.02.039

Todaro, C.M. and Vogel, H.C. Fermentation and Biochemical Engineering Handbook. William Andrew, Norwich, (2014).

Tomás-Pejó, E., Oliva, J., González, A., Ballesteros, I. and Ballesteros, M., Bioethanol production from wheat straw by the thermotolerant yeast Kluyveromyces marxianus CECT 10875 in a simultaneous saccharification and fermentation fed-batch process, Fuel, 88, 2142-2147 (2009). https://doi.org/10.1016/j.fuel.2009.01.014

Yasuda, M., Ishii, Y. and Ohta, K., Napier grass (Pennisetum purpureum Schumach) as raw material for bioethanol production: Pretreatment, saccharification, and fermentation, Biotechnology and Bioprocess Engineering, 19, 943-950 (2014). https://doi.org/10.1007/s12257-014-0465-y 
